\title{
Miskonsepsi Siswa Sekolah Menengah Pertama (SMP) terhadap Bilangan Bulat, Operasi dan Sifat-Sifatnya
}

\author{
Ratnah Kurniati M.A. ${ }^{1}$, Ruslan $^{2}$, Hisyam Ihsan ${ }^{3}$ \\ ${ }^{1}$ Pendidikan Matematika FKIP Universitas Pejuang Republik Indonesia \\ ${ }^{2}$ Pendidikan Matematika FMIPA Universitas Negeri Makassar \\ ${ }^{3}$ Pendidikan Matematika FMIPA Universitas Negeri Makassar
}

E-mail: ratnahkurniati@gmail.com ${ }^{1}$

\begin{abstract}
Abstrak
Penelitian ini bertujuan untuk mengetahui 1) miskonsepsi yang dialami siswa SMP Negeri 2 Sungguminasa terkait dengan bilangan bulat, operasi dan sifat-sifatnya, dan 2) faktorfaktor yang menyebabkan miskonsepsi-miskonsepsi tersebut. Dalam penelitian ini digunakan 38 siswa sebagai subjek penelitian yang kemudian diseleksi dengan tes uraian untuk menentukan siswa mana yang mengalami miskonsepsi. Selanjutnya, setelah terpilih beberapa siswa yang mengalami miskonsepsi berbeda-beda, peneliti melakukan wawancara untuk menelusuri faktor-faktor penyebab terjadinya miskonsepsi yang ada. Metode analisis yang digunakan adalah analisis deskriptif kualitatif. Hasil penelitian menunjukkan bahwa: (1) Miskonsepsi yang dialami subjek penelitian dalam menyelesaikan soal bilangan bulat, operasi dan sifat-sifatnnya adalah dalam: a) membandingkan nilai bilangan bulat, b) penjumlahan dan pengurangan bilangan bulat, c) perkalian dan pembagian bilangan bulat, d) operasi campuran, e) menyederhanakan persamaan linear satu variabel, dan f) memahami sifat distributif. (2) Penyebab miskonsepsi ini adalah: a) kecenderungan siswa yang mengartikan bilangan yang bernilai lebih besar akan berada lebih jauh dari nol, b) kesalahpahaman dalam memahami aturan "bilangan negatif dikali bilangan negatif hasilnya bilangan positif", c) kesalahpahaman dalam memahami fungsi tanda negatif, d) kecenderungan siswa yang menyamakan operasi pembagian sebagai pengurangan atau operasi operasi penjumlahan sebagai perkalian, d) kesalahpahaman dalam mengaplikasikan sifat komutatif, dan e) kesalahan dalam memahami aturan distributif, dimana siswa mengalikan semua bilangan yang ada tanpa memperhatikan letak tanda kurung.
\end{abstract}

Kata kunci: Miskonsepsi, Bilangan Bulat, Operasi, matematika, SMP.

\begin{abstract}
The objectives of this research were to identify SMP Negeri 2 Sungguminasa's students' 1) misconceptions in integers, their operations and their properties, and 2) the causes of these misconceptions. In this research there were 38 subjects given a test to find out which student had a misconception. Then, after choosing some students who have different misconceptions, the researcher interviewed them to know about the causes of these misconceptions. The analysis method used in this research was descriptive qualitative analysis. The result of this research are: (1) Students in SMP Negeri 2 Sungguminasa had misconceptions in: a) comparing the value of integers, b) adding and subtracting integers, c) multiplication and division of integers, d) in mixed operations, e) in simplifying linear equation with one variable, and f) distributive law. (2) The causes of these misconceptions are: a) students' assumed that the larger the number is the farther it is from zero, b) students' misconception in understanding rule "a negative number times a negative number is a positive number", c) students' misconception in understanding about the function of the minus sign, d) students' tended to equate division as subtraction, or addition as multiplication, and e) students' though that to apply the distributive rule, they had to multiply all the numbers involved.
\end{abstract}

Key word: misconception, integer, operation, mathematics, junior high school. 


\section{PENDAHULUAN}

Berdasarkan

konstruktivisme, dikonstruksi secara unik oleh setiap individu. Seorang individu akan mengkonstruksi pengetahuannya secara aktif dan menginterpretasikan informasi baru dalam struktur kognitif mereka.

Sanger \& Greenbowe (dalam Purtadi \& Permana, n.d.) menggambarkan pengetahuan yang diberikan guru ke siswa tidak seperti memberi permen kepada anak kecil, melainkan melalui proses yang lebih kompleks. Siswa harus mengolah kembali dan mengevaluasi pengetahuan baru yang diberikan dengan menggunakan pengetahuan awal yang dimilikinya. Jika pengetahuan baru ini sejalan dengan pengetahuan yang sudah ada, maka pengetahuan ini akan diasimilasikan, tetapi jika kontradiktif maka akan dilakukan akomodasi pengetahuan agar sesuai dengan pengetahuan baru.

Pengetahuan awal yang dimaksud di sini bisa berupa pengetahuan yang memang mereka peroleh di sekolah pada tingkatan sebelumnya atau pengetahuan bawaan yang berasal dari keluarga. Seperti yang diungkapkan Tirtaraharja dan Sulo (2005: 162) "manusia selama hidupnya selalu akan mendapat pengaruh dari keluarga, sekolah dan masyarakat luas, ketiga lingkungan itu sering disebut tripusat pendidikan, yang akan mempengaruhi manusia secara bervariasi." Hal senada juga disampaikan Mestre (dalam Allen, 2007: 1) "they (students) come with informal theories constructed from everyday experience."

Jadi, sebelum memasuki dunia sekolah, seorang anak sudah terlebih dahulu menerima pendidikan dari lingkungan keluarga. Hal ini merupakan salah satu penyebab ketidakmerataannya daya tangkap siswa dalam menerima pelajaran formal di sekolah. Terkadang ada siswa yang belum memahami konsep yang disampaikan sementara yang lainnya sudah paham betul. Momen-momen seperti inilah yang kadang menimbulkan sebuah kesalahpahaman konsep atau miskonsepsi.

Miskonsepsi dalam pelajaran matematika bisa menjadi masalah serius jika tidak segera diatasi, karena miskonsepsi atau kesalahpahaman ini dapat mengakibatkan kesalahan-kesalahan yang berlanjut. Sebab sebuah konsep dasar dalam matematika akan terus diterapkan pada materi berikutnya (Asep Jihad, dalam Subhan, 2009: 4). Jika seorang siswa sudah mengalami miskonsepsi di awal materi (materi dasar), maka sudah dapat dipastikan siswa tadi akan terus mengalami kesalahan yang sama sampai mereka menyadari bahwa miskonsepsi atau kesalahpahaman yang semula mereka yakini benar adalah salah dan pada akhirnya mereka mau menerima konsep yang sebenarnya. Dan membuat mereka mengubah konsep salah yang sudah tertanam ini tentu tidaklah mudah, karena mengubah miskonsepsi berarti mengubah bagian internal yang sudah menjadi "kepercayaan" siswa (Allen, 2007).

Berdasarkan jurnal Allen (2007), Vlassis (dalam Kilhamn, 2011: 46), dan Gelman \& Gallistel (dalam Bofferding, 2011: 12) diketahui bahwa miskonsepsi dalam operasi bilangan bulat memberi dampak besar terhadap pemberian materi pembelajaran selanjutnya. Kekeliruan siswa dalam penjumlahan bilangan bulat berakar dari kesalahan mereka dalam memahami konsep dasar operasi hitung bilangan bulat itu sendiri.

Berdasarkan latar belakang di atas, maka tujuan penelitian ini adalah untuk mengetahui miskonsepsi yang dialami siswa SMP dalam bilangan bulat, operasi dan sifat-sifatnya serta faktor penyebab terjadinya miskonsepsi tersebut.

\section{METODE PENELITIAN}

Penelitian ini dilaksanakan pada bulan Juni 2015 dengan siswa kelas VII.4 
SMP Negeri 2 Sungguminasa tahun ajaran 2014/2015 sebagai subjek penelitian. Adapun pelaksanaan penelitian ini menggunakan metode penelitian deskriptif.

Dalam pelaksanaannya, seluruh subjek penelitian diberi tes uraian terlebih dahulu untuk mendeteksi siswa mana yang mengalami miskonsepsi mengenai bilangan bulat, operasinya serta sifatsifatnya. Selanjutnya, dengan mempertimbangkan jawaban siswa yang kemungkinan mengalami miskonsepsi, pendapat guru bidang studi matematika, serta kemampuan komunikasi siswa maka dipilih 6 orang siswa untuk diberi tes wawancara terstruktur.

\section{HASIL DAN PEMBAHASAN}

Tes dilaksanakan pada hari Jumat, 19 Juni 2015 mulai pukul 14.00 - 14.30 di kelas VII.4 SMP Negeri 2 Sungguminasa dengan siswa berjumlah 38 orang dengan tujuan untuk mengetahui sejauh mana miskonsepsi siswa dalam bilangan bulat, operasi dan sifat-sifatnya. Setelah melihat hasil tes, diketahui bahwa $18 \%$ siswa miskonsepsi dalam menentukan nilai serta letak bilangan bulat pada garis bilangan, $7 \%$ siswa miskonsepsi dalam penjumlahan bilangan bulat, 9\% siswa miskonsepsi dalam pengurangan bilangan bulat, $25 \%$ siswa miskonsepsi dalam perkalian dan pembagian, $42 \%$ siswa miskonsepsi dalam operasi campuran, $30 \%$ siswa miskonsepsi dalam menyederhanakan persamaan linear satu variabel, 5\% siswa miskonsepsi dalam menyelesaikan persamaan linear, dan sebanyak $22 \%$ siswa miskonsepsi dalam memahami sifat distributif.

Berdasarkan hasil wawancara diketahui bahwa pemahaman siswa mengenai bilangan bulat, operasi dan sifatsifatnya berdasarkan hasil tes dan wawancara adalah sebagai berikut:

Hasil analisis data berdasarkan tes dan wawancara menunjukkan bahwa:

1. Siswa AP mengalami kesalahan dalam menentukan besarnya nilai suatu bilangan karena menurutnya bilangan yang bernilai lebih besar berada lebih jauh dari 0 . Alasan inilah yang menyebabkan AP kesulitan dalam membandingkan besarnya nilai bilangan bulat positif dengan bilangan bulat negatif.

2. Siswa AP mengalami kesalahan dalam memahami operasi campuran karena menurutnya apabila tanda negatif (-) sudah berfungsi sebagai tanda 'kurang', maka tanda tersebut sudah tidak dapat berfungsi sebagai negatif.

3. Siswa AP mengalami kesalahan dalam menyederhanakan persamaan linear satu variabel karena AP sengaja mengubah operasi " + " menjadi " $X$ " dan berdalih ada rumus yang mengatakan demikian.

4. Siswa AP mengalami kesalahan dalam memahami sifat distributif karena sengaja mengabaikan tanda "+" dan menganggapnya sebagai " $X$ ".

5. Siswa AP mengalami kesalahan dalam perkalian karena menganggap $\mathrm{a} \times \mathrm{a}=\mathrm{a}$.

6. Siswa NS mengalami kesalahan dalam penjumlahan dan pengurangan bilangan bulat karena salah memahami aturan "negatif kali negatif hasilnya positif", sedangkan NS memahaminya sebagai "negatif ketemu negatif hasilnya positif". Perlu ditekankan, kesalahan NS terjadi karena menggunakan kata 'ketemu' (seharusnya menggunakan 'kali').

7. Siswa NS mengalami kesalahan dalam perkalian karena menganggap $\mathrm{a} \times \mathrm{a}=\mathrm{aa}$.

8. Siswa NS mengalami kesalahan dalam penulisan jawabannya karena salah pengertian terhadap makna tanda ' $=$ '. NS memaknai ' $=$ ' sebagai pengganti kata 'kemudian' atau 'selanjutnya'.

9. Siswa NS mengalami kesalahan dalam operasi campuran karena menganggap sifat komutatif juga berlaku pada pengurangan. 
10. Siswa NS mengalami kesalahan dalam operasi campuran karena menganggap $2 \div 2=0$.

11. Siswa NS, mengalami kesalahan dalam menyederhanakan persamaan linear satu variabel karena mengalikan soal yang seharusnya merupakan operasi penjumlahan.

12. Siswa RM, mengalami kesalahan dalam menyederhanakan persamaan linear satu variabel karena menganggap dalam menyederhanakan variabel, yang harus dihasilkan adalah bentuk paling singkat. Sedangkan bentuk paling singkat ini hanya diperoleh dengan menjumlahkan bilangan-bilangan konstannya. Atau dengan kata lain, mengabaikan variabel-nya.

13. Siswa DW mengalami kesalahan dalam penjumlahan bilangan bulat karena menganggap jika tanda '-' sudah berfungsi sebagai tanda kurang, maka, tanda tersebut sudah tidak lagi berfungsi sebagai negatif.

14. Siswa ZA mengalami kesalahan dalam menyederhanakan persamaan linear satu variabel karena menjumlahkan bilangan yang bervariabel dengan yang tidak bervariabel, walau kemudian menyisipkan variabel dihasil akhir. Akan tetapi, keesokan harinya ZA menyadari letak miskonsepsi ini dan memperbaikinya.

Berdasarkan kesalahan-kesalahan siswa di atas, dapat dikatakan terdapat miskonsepsi yang dialami sebagian siswa beserta penyebab terjadinya pada beberapa siswa SMP dalam bilangan bulat, operasi dan sifat-sifatnya adalah:

a. Ada miskonsepsi dalam menentukan besarnya nilai suatu bilangan.

Penyebab miskonsepsi pada indikator ini adalah ada siswa yang mengganggap bahwa suatu bilangan akan bernilai lebih besar jika letaknya berada lebih jauh dari 0 .
Miskonsepsi seperti ini juga disebutkan dalam jurnal Allen (2007: 4) yang mengemukakan beberapa miskonsepsi dalam aritmetika, dimana salah satu poinnya tentang miskonsepsi dalam menentukan besarnya nilai suatu bilangan bulat negatif (magnitudes for negative numbers). Dalam Allen (2007: 4) diberikan contoh "which number is larger -8 or -5 ?". Menurutnya, "the problem here is how the student perceives "large." Some teachers mistakenly use expressions such as the "larger negative value." This causes confusion to many students."

b. Ada miskonsepsi dalam penjumlahan dan pengurangan bilangan bulat

Penyebab miskonsepsi ini adalah

1) Ada siswa yang salah dalam memahami aturan "negatif kali negatif hasilnya positif". Siswa tersebut memahami aturan ini sebagai "negatif ketemu negatif hasilnya positif". Perlu ditekankan, kesalahan ini terjadi karena menggunakan kata ketemu bukan kali.

Dalam Allen (2006: 4) dikatakan "it is helpful to confront students with counterexamples to their misconceptions". Jadi, untuk menghilangkan miskonsepsi ini, siswa terlebih dahulu diberi contoh penjumlahan bilangan bulat positif, penjumlahan bilangan bulat negatif, penjumlahan berulang (perkalian) bilangan bulat positif, penjumlahan berulang (perkalian) bilangan bulat negatif, barulah kemudian siswa diminta menarik kesimpulan mengenai konsep awalnya yang mengatakan "negatif ketemu negatif hasilnya positif”.

2) Ada siswa yang menganggap jika tanda negatif (-) sudah berfungsi sebagai tanda kurang (binary function), maka, tanda tersebut sudah tidak lagi berfungsi sebagai bilangan negatif (unary function).

Dalam Lovell (2004: 14) dikatakan "it may also be possible to over use 'realistic' contexts in the early stages of teaching algebra". Jadi, dapat dikatakan salah satu 
cara untuk menghilangkan miskonsepsi ini adalah dengan mengajukan pertanyaan yang sama namun dalam konteks kehidupan sehari-hari, misalnya dengan mengganti kata 'kurang' dengan 'hutang' dan mengganti 'nilai bilangan bulat' dengan 'uang'.

c. Ada miskonsepsi dalam perkalian dan pembagian bilangan bulat

Penyebab miskonsepsi ini adalah ada siswa yang cenderung menyamakan operasi pengurangan dengan operasi pembagian atau menyamakan operasi penjumlahan dengan operasi perkalian.

Menurut Allen (2006: 4) "it is helpful to confront students with counterexamples to their misconceptions". Jadi, dapat dikatakan salah satu cara untuk menghilangkan miskonsepsi ini adalah dengan memberikan contoh dengan operasi berbeda untuk bilangan yang sama, sehingga nantinya siswa akan menemukan perbedaan dari keempat operasi ini dan menyadari letak kesalahannya.

\section{d. Ada miskonsepsi dalam memahami operasi campuran.}

Penyebab miskonsepsi ini adalah

1) Ada siswa yang menganggap jika tanda '-' sudah berfungsi sebagai tanda kurang, maka, tanda tersebut sudah tidak lagi berfungsi sebagai negatif.

Miskonsepsi seperti ini juga dikemukakan Kilhamn (2011:44) "The minus sign is used both as a sign of operation (substraction) and as a sign indicating a negative number (polarity). Many researchers have studied procedural errors that are caused by students' lack of conceptual understanding of the minus sign."

2) Ada siswa yang mengaplikasikan sifat komutatif pada pengurangan, padahal jelas bahwa sifat komutatif hanya berlaku pada penjumlahan dan perkalian saja.

Strategi untuk mengatasi miskonsepsi menurut Lochead \& Mestre (Allen, 2006:

3) terdiri dari 3 tahap, yaitu: probe for and determine qualitative understanding; probe for and determine quantitative understanding; and probe for determine conceptual reasoning. Jadi, yang harus dilakukan adalah menjelaskan kembali tentang definisi dari sifat komutatif, kemudian meminta siswa menemukan sendiri operasi mana saja yang bersifat komutatif serta menentukan apakah pengurangan bersifat komutatif atau tidak.

e. Ada miskonsepsi dalam menyederhanakan persamaan linear satu variabel.

Penyebab miskonsepsi dalam indicator ini adalah:

1) Ada siswa yang sengaja mengubah operasi " + " menjadi " $x$ " dan berdalih ada rumus yang mengatakan demikian.

2) Ada siswa yang cenderung mengesampingkan variabel dan menjumlahkan semua bilangan konstan (baik yang memiliki variabel ataupun tidak), kemudian hasilnya nanti berupa bilangan konstan yang 'diberi' variabel sesuai dengan yang ada pada soal.

3) Ada siswa yang menganggap dalam menyederhanakan variabel, yang harus dihasilkan adalah bentuk paling singkat sehingga semua bilangan konstan, baik yang bervariabel maupun tidak harus dijumlahkan, dan hasilnya nanti berupa bilangan konstan.

Miskonsepsi yang sama juga dikemukakan dalam Lovell (2004: 14) dan mengatakan beberapa strategi untuk mengatasi miskonsepsi siswa ini, bisa dengan menggunakan objek sebagai pengganti variabel, misalnya soal $3 m+6$ diubah menjadi 3 miles +6 . Atau, dikatakan dalam Lovell (2004: 15)

"On the one hand the pupil believes that the two expressions are equivalent, on the other they see that they give different results when values are substituted into them. In this situation the pupil can see that something has to be wrong, and can even be invited to 
explain and resolve this colflict for him- or herself. Even if the pupil is unable to resolve this conflict, the awareness of it is likely to make him or her more receptive to resolutions offered by the teacher or by other students."

Jadi dikatakan bahwa cara lainnya adalah dengan memberikan siswa beberapa soal yang ekuivalen, dimana siswa menyadari bahwa soal-soal tersebut ekuivalen. Selanjutnya, saat mengerjakan beberapa soal ekuivalen ini siswa akan menemukan jawaban berbeda ketika nilai yang mereka peroleh disubtitusikan ke dalamnya. Kemudian siswa akan menyadari adanya kesalahan, dan menjelaskan kesalahannya sekaligus menyelesaikan konflik dalam dirinya.

\section{f. Ada miskonsepsi dalam memahami sifat distributif}

Penyebab miskonsepsi ini adalah ada siswa yang menganggap dalam mengaplikasikan sifat distributif ia harus mengalikan semua bilangan yang ada, misalnya pada soal $3(a+2)+2 a$ dimana jawabannya adalah $3(a+2)+2 a=$ $3 a+6+6 a$.

Salah satu cara mengatasi miskonsepsi menurut Swan (dalam Lovell, 2004: 15) "the approach has the benefit of bringing about a 'cognitive conflict'." Jadi miskonsepsi ini bisa diatasi dengan memberikan siswa beberapa soal yang ekuivalen, dimana siswa menyadari bahwa soal-soal tersebut ekuivalen. Selanjutnya, saat mengerjakan beberapa soal ekuivalen ini siswa akan menemukan jawaban berbeda (padahal seharusnya jawabannya sama). Misalnya siswa di dalam kelas diberikan soal $3(a+2)+2 a$ dan $2 a+3(a+2)$ untuk dikerjakan bersama. Nantinya, hasil yang mereka peroleh didiskusikan, selanjutnya siswa akan menyadari sendiri adanya kesalahan dan menjelaskan kesalahannya sekaligus menyelesaikan konflik dalam dirinya.
g. Ada miskonsepsi dalam penulisan jawaban

Penyebab miskonsepsi ini adalah ada siswa yang salah pengertian terhadap makna tanda ' $=$ '.

Miskonsepsi yang sama juga dijelaskan dalam Lovell (2004: 17). Di sini dikatakan "remedy for such mistakes is the practice of reading the offending statement aloud. I would suggest that when using this strategy, it might sometimes be valuable to replace word 'equals' with a synonym such as 'is-the-same-as'." Dikatakan Lovell, sebaiknya sesekali guru mengganti kata "sama dengan" untuk "=" dengan kata lain yang serupa. Selain itu, untuk guru juga disarankan dalam menulis tanda sama dengan di papan tulis sebaiknya menuliskannya secara simetris. Seperti yang dikatakan dalam Lovel (2004: 17) "other useful strategies include emphasizing the symmetry of the equals sign."

\section{SIMPULAN}

Berdasarkan hasil tes bilangan bulat dan wawancara kepada siswa, maka dapat diperoleh:

1. Miskonsepsi-miskonsepsi yang dialami beberapa siswa SMP Negeri 2 Sungguminasa dalam menyelesaikan soal bilangan bulat, operasi dan sifatsifatnya adalah:

a. Miskonsepsi dalam membandingkan nilai bilangan bulat yang disebabkan karena ada siswa menganggap bahwa sebuah bilangan akan bernilai lebih besar jika berada lebih jauh dari 0 pada garis bilangan.

b. Miskonsepsi dalam penjumlahan dan pengurangan bilangan bulat.

Penyebabnya adalah ada siswa yang miskonsepsi dalam memahami aturan "bilangan negatif kali bilangan negatif hasilnya adalah positif', selain itu, ada siswa yang mengalami miskonsepsi karena kurang memahami fungsi tanda negatif.

c. Miskonsepsi dalam perkalian dan pembagian bilangan bulat. 
Penyebabnya adalah ada siswa yang cenderung menyamakan operasi pengurangan dengan operasi pembagian atau menyamakan operasi penjumlahan dengan operasi perkalian.

d. Miskonsepsi dalam operasi campuran. Penyebabnya adalah siswa mengalami miskonsepsi dalam memahami fungsi tanda negatif (negativity), selain itu, miskonsepsi ini juga oleh siswa lainnya timbul karena kesalahan pengaplikasian sifat komutatif.

e. Miskonsepsi dalam menyederhanakan persamaan linear satu variabel disebabkan oleh sebagian siswa yang menganggap operasi ' + ' sebagai ' $X$ ' serta pengabaian variabel.

f. Miskonsepsi dalam memahami sifat distributif. Penyebabnya adalah sebagian siswa cenderung menganggap dalam mengaplikasikan sifat distributif mereka harus mengalikan semua bilangan yang ada dalam operasi.

2. Ditemukan sebuah temuan lain yaitu ada siswa yang mengalami miskonsepsi dalam memaknai tanda 'sama dengan' $(=)$.

\section{DAFTAR PUSTAKA}

Allen, G. D. (2007). Student Thinking:

Lesson 1. Misconceptions in

Mathematics. Departement of

Mathematics: Texas A\&M

University. Diakses pada 4 April

2012 dari

http://www.math.tamu.edu/ snite/Mi sMath.pdf

Allen, G.D. (2006). Student Thinking. Diakses pada 6 Februari 2013 dari http://mtc.tamu.edu/9-12/M2_912.pdf

Bofferding, L.C. (2011, May). Expanding the numerical central conceptual structure: first graders' understanding of integers. Stanford University. Diakses pada 22 Oktober 2012, dari https://stacks.stanford.edu/file/druid: hk239ky7693/negativenumbers\%20[for\%20online\%20sub mission]-augmented.pdf.

Kilhamn, C. (2011). Making Sense of negative numbers. Diakses pada 4 April 2012, dari https://gupea.ub.gu.se/bitstream/207 7/24151/1/gupea_2077_24151_1.pdf

Lovell, S. (2004). Pupils' Misconceptions in Mathematics. Diakses pada 26 November 2012 dari http://myweb.tiscali.co.uk/annotation s/content/maths_misconceptions.pdf

Purtadi, S. \& Permana, L.S. (n.d.). Analisis Miskonsepsi Konsep Laju dan Kesetimbangan Kimia pada Siswa SMA. FMIPA : UNY. Diakses pada 18 Oktober 2012, dari situs http://staff.uny.ac.id/sites/default/file s/Makalah\%20Semnas\%20MIPA\%2 0 -

\%20Analisis\%20Miskonsepsi\%20K onsep $\% 201$ aju $\% 20$ dan $\% 20$ Kesetimb angan\%20Kimia_0.pdf

Subhan. (2009). Analisis Miskonsepsi Siswa dalam Menyelesaikan Soal Uraian Berbentuk Cerita pada Bidang Studi Matematika. Diakses pada 9 Oktober 2012, dari situs http://blog.tp.ac.id/wpcontent/uploads/7185/download-

Tirtaraharja, U. \& Sulo, S.L.L. (2005). Pengantar Pendidikan. Jakarta: PT Asdi Mahasatya. 